\title{
Chemical and Biological Warfare: Should Rapid Detection Techniques Be Researched To Dissuade Usage? A Review
}

\author{
Mark R. Hurst and Ebtisam Wilkins \\ Department of Chemical and Nuclear Engineering \\ University of New Mexico, Albuquerque, New Mexico 87131
}

\begin{abstract}
Chemistry, microbiology and genetic engineering have opened new doorways for the human race to propel itself to a better future. However, there is a darker side to Bioengineering. One element of this is the manufacture and proliferation of biological and chemical weapons. It is clearly in the interest of humankind to prevent the future use of such weapons of mass destruction. Though many agents have been proposed as potential biological and chemical weapons, the feasibility of these weapons is a matter of conjecture. The unpredictable and indiscriminate devastation caused by natural epidemics and hazardous chemicals during wartime without medical treatment should warn humans of the dangers of employing them as weapons. This study argues rapid detection techniques may dissuade future use. Many agents are far less toxic to treatment. A quick response time to most attacks will decrease the chances of serious health issues. The agent will be less effective and discourage the attacker from using the weapon. Fortunately, the Chemical and Biological Weapons Convention (CWCIBWC) allows defensive work in the area of biological and chemical weapons. Consequently, the review will discuss history, delivery/dispersal systems and specific agents of the warfare. The study presents current developments in biosensors for toxic materials of defense interest. It concludes with future directions for biosensor development.
\end{abstract}

Key words: Biological and chemical weapons, rapid detection techniques, health issues

\section{INTRODUCTION}

History: Biological and chemical warfare has been attempted many times in past centuries. In 1347, the Tatars used catapults to hurl their dead bodies infected by plague during the siege of $\mathrm{Caffa}^{[1]}$. The British gave American Indians smallpox in the colonial days. In World War II ${ }^{[2]}$, one million men were wounded by gas and ninety thousand $\operatorname{died}^{[3]}$. During the 1930s, the Italian army gassed Ethiopians and Japan launched more than eight hundred gas attacks in its invasion of China ${ }^{[4]}$. The Japanese also are believed to have conducted experiments with agents in thousands of Chinese prisoners of war $^{[3]}$. In World War II, chemical and biological weapons could have been far more extensive. German factories were capable of producing approximately eleven thousand tons of poisonous gas per month ${ }^{[5]}$. The British biological warfare project was years ahead of the Germans. They produced five million cattle cakes packed with anthrax. Even the United States had a plan to use the anthrax bomb against Germany ${ }^{[1,5-7]}$. The threat of chemical and biological weapons of mass destruction has intensified because of advances in chemistry, genetics and other sciences $^{[6]}$. The United States stockpiled approximately thirty-six thousand tons of chemical warfare agents before production stopped in $1969^{[5]}$. These agents include phosgene gas, hydrogen cyanide, mustard gas and nerve gas ${ }^{[6]}$. The stockpile of nerve gas in the United States alone is said to be sufficient to kill the entire population of the world four thousand times ${ }^{[6-8]}$.
The Soviets are believed to have stockpiled two hundred seventy thousand to three hundred sixty thousand tons of chemical agents ${ }^{[7]}$. These agents include phosgene gas, newer agents, hydrogen cyanide and blistering agents ${ }^{[7,9,10,11]}$. The 1972 Biological Weapons Convention and the 1993 Chemical Weapons Convention are the most recent international agreements prohibiting these types of weapons ${ }^{[12]}$. Nevertheless, analysts contend that following the IranIraq War, more countries began to develop chemical and biological weapons and the threat of their employment has become greater. Iraq in particular has been charged of stockpiling such weapons. Iraqi resistance to United Nations weapons inspections in the late 1990s raised international awareness of the need for stronger efforts to control biological and chemical weapons ${ }^{[13-15]}$.

\section{Chemical Warfare:}

Common Agents: A United Nations report from 1969 and beyond ${ }^{[16]}$ defines chemical warfare agents as "... Chemical substances, whether gaseous, liquid or solid, which might be employed because of their direct toxic effects on man, animals and plants..." ${ }^{[16-25]}$. Chemical weapons can cause injury several ways. Most cause injury when inhaled and some cause injury through contact with skin or through the intake of contaminated food $^{[17]}$. The agents can be grouped into two general types. Agents that affect the body surface they contact and those that damage the general nervous system ${ }^{[18-25]}$. 
Surface: Surface agents include phosgene gas, chlorine gas, hydrogen cyanide and mustard gas ${ }^{[17]}$. The main action of phosgene, chlorine and hydrogen cyanide occurs through inhalation. Phosgene is a choking agent that causes the lungs to fill with water. Chlorine destroys the cells that line the respiratory tract. Hydrogen cyanide blocks oxygen from reaching the blood. A toxic effect of hydrogen cyanide is by inhibiting the metal-containing enzymes. One such enzyme is cytochromoxidase ${ }^{[18-25]}$. This enzyme system is responsible for the energy-providing processes in the cell where oxygen is utilized. When cell respiration stops, it is no longer possible to maintain common cell functions, which leads to cell death ${ }^{[16-22]}$. Mustard gas is composed of tiny droplets of liquid that are dispersed in the air, where they are inhaled like a gas. It is a blistering agent that damages any surface it contacts, including the skin, eyes and lungs. It usually causes death by respiratory failure ${ }^{[17]}$. There is no treatment or antidote for mustard agent injury. As an alternative, efforts must be made to treat the symptoms. By far the most important measure is to rapidly decontaminate the patient and thereby prevent further exposure ${ }^{[26-33]}$. The skin is washed with soap and water and the eyes are rinsed with water or a salt solution for at least five minutes ${ }^{[26-33]}$.

Nerve: Nerve agents act by blocking the transmission of nerve messages ${ }^{[17]}$. These agents include salmon, soaring, Tabun and VX. If inhaled or absorbed through the skin, a single drop of nerve agent can shut down the body's nervous system. The most powerful is VX, but all can cause death within minutes after exposure. Herbicides are chemicals that kill vegetation. Agent Orange, a herbicide, was used during the Vietnam War to destroy jungle leaves to expose enemy troops. Some people regard herbicides, as chemical weapons if used for hostile purposes, but there is no universal agreement about this. However, Vietnam War veterans suffered several health problems blamed on exposure to agent orange and other toxins ${ }^{[13-15]}$. Symptoms for nerve agent are increased production of saliva, a running nose, secretion of mucous in the respiratory system and a feeling of pressure on the chest. More unspecific symptoms are tiredness, slurred speech, nausea and hallucinations ${ }^{[18]}$. Nerve agents have an extremely quick effect. If treatment is to serve any purpose, they must be introduced immediately. In many nations, the armed forces have access to an auto-injector containing antidotes to nerve agents ${ }^{[26-33]}$. It is so easy to use that a soldier can give himself or another person an injection. Unfortunately, total protection from chemical attacks is difficult, but quick detection will reduce the effects.

Delivery ${ }^{[34]}$ : A chemical attack involves dispersing agents into the air. This can be done in various ways, such as firing artillery shells that burst in midair, or using airplanes to spray the agents. Chemical weapons were generally designed with two objectives in mind. The first objective is comparable to existing weapons systems. For example, chemical shells that can be fired from the same guns as conventional artillery shells or chemical bombs that can be dropped from the same airplanes as conventional bombs. The second objective is sufficient generation of an aerosol of chemical weapons agent at the target.

There are many types of delivery systems. Chemical artillery shells contain a reservoir filled with a chemical agent surrounding an explosive charge. When the shell arrives at its target, the chemical to disperse as an aerosol. A chemical agent land mine contains a reservoir filled with a chemical agent surrounding an explosive charge (Fig. 1).

The top of the land mine has a pressure plate. When the pressure plate is depressed, the mine detonates and causes the chemical agent to disperse as an aerosol (Fig. 2).

The rocket is probably the most hazardous chemical weapon in the U.S. stockpile from a safety standpoint. As the rocket propellant ages, it becomes unstable.

Soaring-containing rockets poses a particular hazard because fluoride ion in the adding of soaring increase the corrosion of the aluminum body of the rocket (Fig. 3). Chemical bombs contain a reservoir filled with a chemical agent surrounding an explosive charge (Fig. 4).

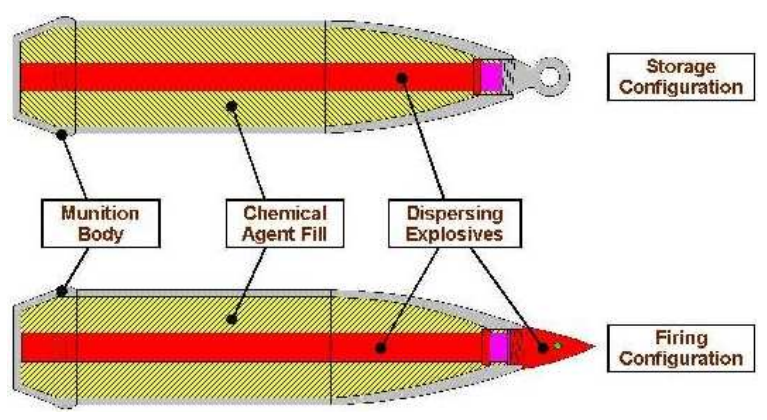

Fig. 1: Artillery Shell ${ }^{[34,35]}$ (Mitretek)

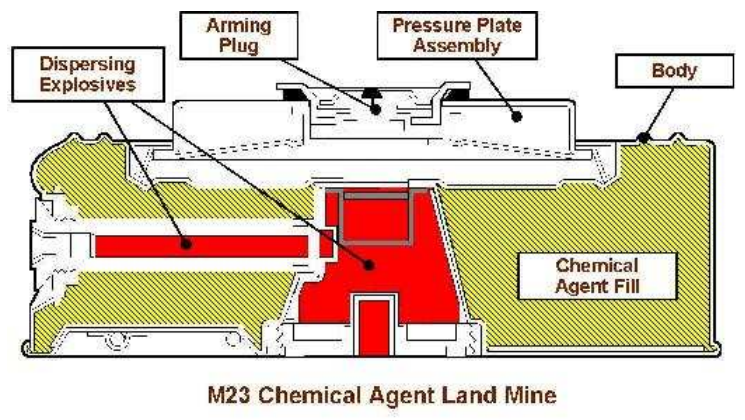

Fig. 2: Land Mine ${ }^{[34,35]}$ (Mitretek) 


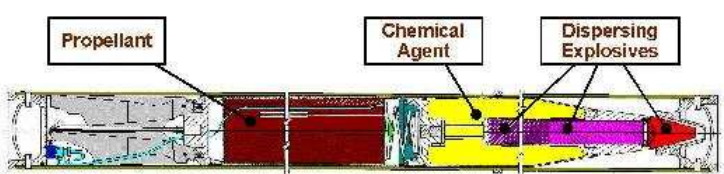

115-mm M55 Chernical Agent Rocket (in shipping and firing container)

Fig. 3: Rocket $^{[34,35]}$ (Mitretek)

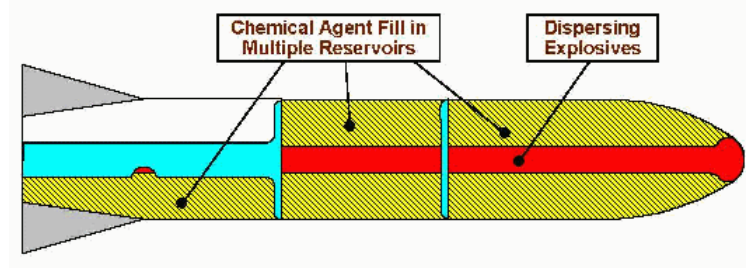

MK-116 Weteye Bomb

Fig. 4: Bomb ${ }^{[34,35]}$ (Mitretek)

Dispersal Factors ${ }^{[35]}$ : Once a chemical weapon has detonated, it creates a "primary cloud". It can be either a solid or liquid aerosol cloud. The cloud then settles to the ground. It lands on individuals and creates ground contamination. The ground contamination then has a fine lifetime. It can injure from direct contact or from contact with a "secondary cloud" of agent that has evaporated from the ground contamination. The factors that affect the danger from the primary cloud are related to the local weather. Factors diminishing the danger of the primary cloud ${ }^{[34,35]}$ :

* Variable wind direction, which causes dilution by redirection of the cloud

* Wind velocity over $6 \mathrm{~m} \mathrm{~s}^{-1}$, which causes dilution of turbulence

* Temperature below $0^{\circ} \mathrm{C}$, which causes less evaporation from liquid or solid aerosol particles. Aerosol particles settle to the ground more quickly than agent vapor

* Precipitation, which washes both aerosol particles and vapor out of the atmosphere

Factors increasing the danger of the primary ${ }^{[34]}$ :

* Steady wind direction

* Wind velocity under $3 \mathrm{~m} \mathrm{~s}^{-1}$

* Stable air (inversion)

* Temperature above $20^{\circ} \mathrm{C}$

* No precipitation

Factors that decrease the danger of ground contamination include ${ }^{[34,35]}$ :
* High ground temperature, which causes decomposition of some agents.

* High wind velocity, which dilutes the agent.

* Unstable air, which diluted the agent.

* Heavy precipitation, which diluted the agent, hydrolyzes the agent and washes the agent into the soil.

Factors that increase the danger of ground contamination are ${ }^{[35]}$ :

* Low wind velocity

* Temperature inversion

* Lifetime of some chemical warfare agents

\section{Biological Warfare}

Common Agents: "The one that scares me to death, perhaps even more so than tactical nuclear weapons and the one we have the least capability against is biological weapons" ${ }^{[25]}$. Biological warfare agents include bacteria, viruses, fungi and other living microorganisms. Since they can reproduce, biological agents have the unique potential to make an environment more hazardous over time. For the purposes of warfare, specific characteristics of certain agents make them more likely to be used than others $^{[36,37]}$.

Anthrax: "The noise of fourteen thousand aero planes advancing in open order. But in the Kurfurstendamm, the explosion of anthrax bombs is hardly louder than the popping of a paper bag". Anthrax is a bacterium of the strain Bacillus Anthraces. It is extremely resistant and infectious. Anthrax is an aerobic gram-positive rod that commonly infects herbivores ${ }^{[38]}$. The bacteria can exist as hardy, shell-like forms called spores. In a warm, moist environment like the human lung, the spores can become highly lethal. Anthrax bacteria are usually found under the soil surface and cause disease primarily in cattle. Spores can withstand temperatures above $100^{\circ} \mathrm{C}$ for limited time periods, making them less fragile than viruses or vegetative bacteria. Humans obtain the disease when they come in contact with infected animals. Within two to five days of exposure, an ulcer forms. Secondary spread to the bloodstream may occur. Death in treating cases is very rare but untreated persons may have a fatality rate around twenty percent ${ }^{[37]}$.

Plague: The disease is caused by Yersinia pestis, a gram-negative aerobic rod that still cause natural diseases in partial areas of the world ${ }^{[37]}$. The organism resides in rodents, especially rats. Fleas acquire the organism when they feed on infected rodents. Disease is spread to humans through the bite of infected fleas. In order to be effective for large-scale biological warfare, infected fleas could be introduced behind enemy lines. Though this might sound awkward, the 
Japanese were experimenting with this during World War II. Within one to six days after the flea-bite, lymph nodes draining the area swell and become irritated. It is very contagious and may result in person-to-person spread $^{[37]}$. Early administration of antibiotics is quite effective, but must be started within twenty-four hours of the symptoms.

Cholera: Cholera is caused by Vibrio cholera. Humans are the main reservoir of the disease, which spreads when infected feces are inadvertently consumed. Adults must ingest large quantities of organisms in order to acquire the disease. To be effective as a biological weapon, major drinking water would have to be contaminated $^{[37]}$. The incubation period ranges from a few hours to a few days. Heavy dehydration follows. Treatment consists of fluid and electrolyte replacement. Without treatment, death may result from severe dehydration $^{[37]}$.

Smallpox: The smallpox virus is transmitted through droplets discharged from the mouth and nose of an infected person that are inhaled by another person. The incubation period ranges from two to five days following infection. Symptoms are a high fever, prostration, back and muscle pain and sometimes vomiting. In 1967 the United Nations World Health Organization commenced a worldwide vaccination campaign against smallpox ${ }^{[16]}$. At the time, about ten to fifteen million cases of the disease occurred each year. Stockpiles of the virus now exist only at the Centers for Disease Control and Prevention in Atlanta, Georgia and the Russian State Research Center of Virology and Biotechnology in Koltsovo, Russian Federation ${ }^{[28]}$.

Q Fever: Originally called Query fever, Q fever is caused by Coxiella burnetii, a type of bacterium known as a Rickettsia. Q fever is a laboratory hazard but remains stable in many environments ${ }^{[34-36]}$. This makes it a very feasible weapon because it can be delivered as an aerosol. Within two to three weeks of exposure, fever and headaches occur. The fatality rate is less than one percent but it spreads very easily ${ }^{[37]}$. If taken early enough in the infection's progress, antibiotics can provide an effective care for $\mathrm{Q}$ fever.

Delivery: Fortunately a missile packed with biological weapons is not entirely effective. Biological agents do not like the huge stresses and gravitational forces that are applied during missile flight. A missile can enter the atmosphere at speeds exceeding mach two. Furthermore, the heat generated by the acceleration and detonation of ballistic missiles makes them less than ideal method of delivering live bacteriological agents. Major drinking water sources are a much better way of releasing biological agents.
Timeline (WGBH, 2001) ${ }^{[39]}$ : 1925 Geneva Protocol: The use of chemical weapons in WWI clearly frightened the scientific community. The Geneva Protocol was established to prohibit the use of such agents in war ever again. The agreement did not ban the research or production of biological agents.

World War II: Despite the Geneva Protocol, chemical weapons appeared in $\mathrm{WWII}^{[1-7]}$. Japan experimented with biological agents throughout the 1930s and 1940s and used biological weapons in China. Japanese military officials tried to poison delegates of the league of Nations' Layton commission that had been assigned to investigate Japan's seizure of Manchuria in $1931^{[1,12-15]}$.

1950s and 1960s United States' Offensive Biological Program: The U.S. expanded its offensive biological warfare program, which started during world War II. The U.S. Army conducted tests secretly in the U.S. cities using nonpathogenic bacteria. At the end of 19659 President Nixon terminated the U.S. biological warfare program and destroyed all U.S. Stockpiles ${ }^{[34-36]}$.

1972 Biological Weapons Convention: The biological Weapons Convention (BWC ${ }^{[25]}$ prohibits the research, development and proliferation of offensive biological weapons. The treaty does, however, allow defensive work in this discipline to carry on.

1980 Eradication of Smallpox: The eradication of smallpox and, to a certain extent, polio after a long and successful vaccination campaign by the Center for Disease Control, based in Atlanta.

1980-1988 Iraq: Chemical weapons were used extensively during the Iran-Iraq war, mainly buy from Iraq. After the Gulf War, in 1991, Iraq was ordered by the UN security Council to stop its biological, chemical and nuclear weapons.

January 1991 Inspection: In 1989 Communism fell. Join U.S./UK inspection teams visited some biological facilities in Russia. They found evidence of an offensive program that involved biological agents, such as smallpox, anthrax and plague. The following December, Russian inspection teams visited the closedup U.S. biological facilities and see that the U.S. ended the offensive program.

1993 Chemical Weapons Convention: The Chemical Weapons Convention (CWC) was established. Similar to the BWC, it prohibits the research and production of chemical agents ${ }^{[25]}$.

February 27, 1993 World Trade Towers Bombing: A bomb exploded at the World Trade Towers in New York City ${ }^{[39]}$. Some analysts suspect the bomb was laced with cyanide that failed to ignite. 


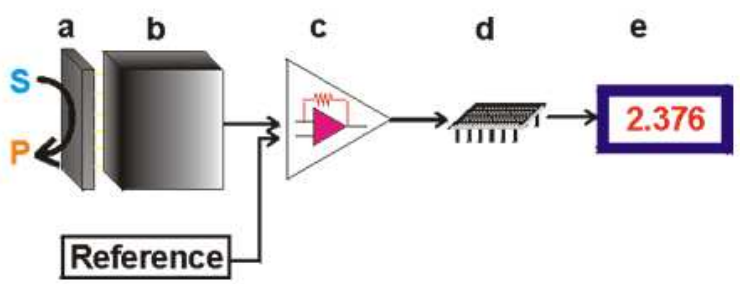

Fig. 5: Schematic Diagram Showing the Main Components of a Biosensor. The Biocatalyst (a) Converts the Substrate to Product. This Reaction is Determined by the Transducer (b) Which Converts it to an Electrical Signal. The Output from the Transducer is Amplified (c), Processed (d) and Displayed (e)



Fig. 6: Schematic of Antigen and Antibody Interaction

March 20, 1995 Tokyo Subway Attack: Members of a religious sect released sarin gas in the Tokyo subway system, killing twelve and injuring over five thousand. Due to the poor quality of the souring agent and an ineffective dispersal system, casualties were lower than expected $^{[39]}$.

May 1998 Presidential Initiatives: President Clinton approved two new Presidential decision directives, known as PDD-62 $2^{[40]}$ and PDD-63 ${ }^{[41]}$, to improve the country's ability to prevent and respond to chemical and biological attacks. An additional one billion is added to the defense budget for chemical and biological defense.

\section{Detection:}

Biosensor Overview: A biosensor is a device that utilizes a biological element to detect an analyst. The detection of an analyte by the biological substrate is then converted into a measurable signal, usually an electronic signal, by a transducer (Fig. 5). The signal is then carried to the signal processor ${ }^{[42]}$. A biosensor can be designed to detect biological organisms or chemical compounds. There are two main components, the affinity layer (the biological detection element) and the transducer. The affinity layer is reactants on the surface of the transducer. This layer is used as a catalyst for detection. There are several types of affinity layers ${ }^{[43-47]}$ :

* A biosensor is an example of such a defense. Biosensors incorporate well-known biological pathways as a method of detection. There are two main parts of this design, the biological-sensing element (affinity layer) and the transducer ${ }^{[43]}$. There are several affinity layer schemes used today. One of the most important of these is the antibody antigen interaction. Detection techniques like the biosensor should be developed because it will discourage attackers from deploying an agent.

* Layers that incorporate smart materials that allow transport to the transducer.

* Layers that are based of chemical interactions, such as antibodylantigen interactions.

* Layers that based on oxidation-reduction reactions, dyes, refraction indexes, fluorescence and many other technologies.

Chemical interaction affinity layers deal with chemical changes at the surface of the biosensor ${ }^{[43]}$. In the antibody antigen affinity layer, an antibody is bound to the transducer. The antibody binds to one or two target antigens that are present in the sample solution. Attached to the antigen are epitopes. These epitopes are specific to each antigen. Antigens are free floating in a stream or attached to a prokaryotic or eukaryotic cell. Each antigen is specific to a certain species/type of cell. For example, anthrax has a specific antigen that is attached to the outside of its membrane; cholera, another pathogen, has a different antigen attached to the surface of the membrane ${ }^{[43-47]}$ (Fig. 6). In essence, antigens are name tags for a cell. This type of marker can then detect specific biological organisms or chemical compounds.

Chemical Agent Sensors: If chemical detection devices were situated in an area of attack, they could signal a dangerous chemical was present. These detection kits might contain treated paper or liquids that change color when certain chemical agents are present ${ }^{[13-15]}$. There has been a continuing effort to develop biosensors for pesticides and nerve agents. An obvious choice for the biological element is the enzymes Acetyl cholinesterase and Butyryl cholinesterase (AChE, BChE), which are available commercially. The change in $\mathrm{pH}$ accompanying the hydrolysis of $\mathrm{AChE}, \mathrm{BChE}$ has been utilized in several biosensors $^{[48]}$. 


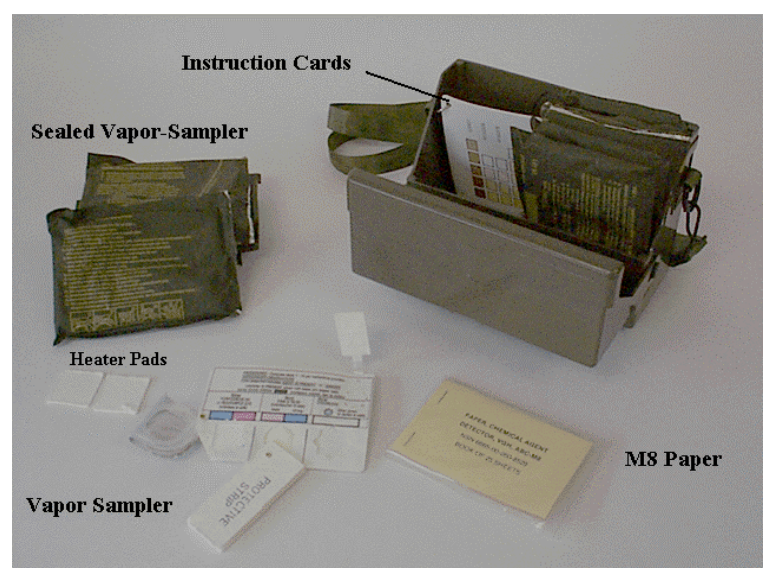

Fig. 7: A M256AI Kit

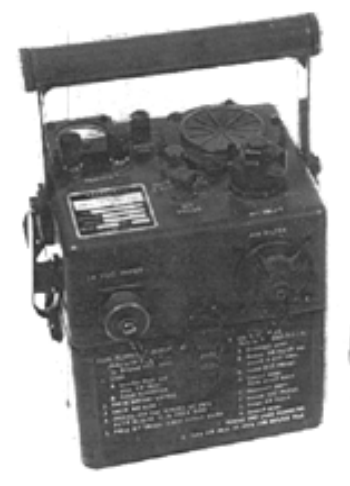

M43A1 Detector

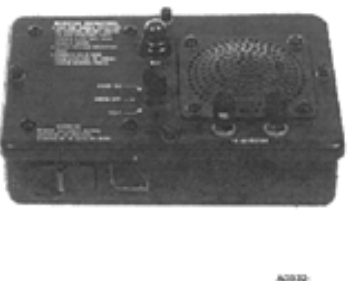

M42 Alarm
Fig. 8: A M8A1 Kit Chemical Agent Detection Kits

M256AI: The most commonly available detectors for determining the presence of chemical agent vapors is the M256A1 Chemical Agent Detector Kit (Fig. 7) $^{[49-52]}$.

These kits contain vials of liquid chemical reagents that are exposed to the air in a specific sequence to indicate the presence of hazardous levels of chemical agents. The kits must be manually manipulated and the full sequence of tests takes twenty to twenty five minutes. Approximately forty-five thousand of these detector kits (each of which contains twelve actual detectors packets) were deployed in the Gulf War ${ }^{[50,51]}$.

M8A1: The M8A1 electronically monitors hazardous levels of nerve agent vapor ${ }^{[50]}$. The M8A1 automatic chemical agent alarm consists of the M43A1 detector unit and the M42 alarm unit (Fig. 8). Once placed into operation, it will run for up to twenty-four hours before needing servicing. The detector component of this system can be displaced upwind from the unit's position. While sensitive, this device is also prone to false positive responses under some conditions due to high concentrations of certain organic compounds ${ }^{[50-52]}$.

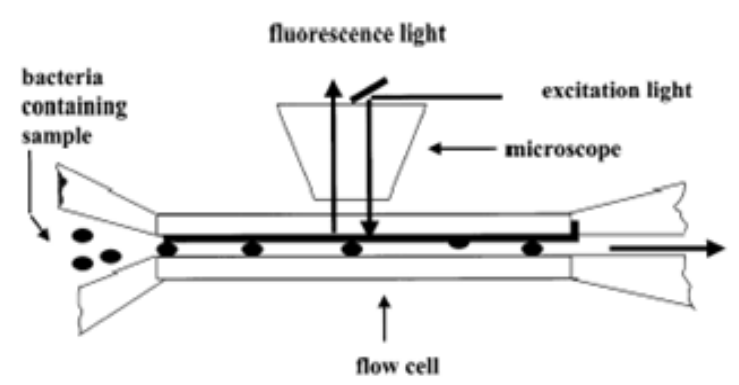

Fig. 9: Schematic of an Optical Sensor for Biological Agents ${ }^{[60]}$

Biological Agent Sensors: Verifying the presence of a biological agent is even more difficult than chemical detection. Even if a biological attack were known to be occurring, quick identification of the offending organism might be difficult. "It is a challenge to create biosensors with the necessary properties for reliable and effective use in routine applications" ${ }^{\text {[53]. The U.S. }}$ military has developed a field apparatus that can test an air sample for the presence of specific biological agents ${ }^{[17]}$, called a Biological Integrated Detection System (BIDS) ${ }^{[54]}$, it can confirm the presence of a handful of microorganisms, including anthrax and plague bacteria. However, there are scores of possible biological agents that cannot be easily detected. Several efforts have been made to develop a generic detector of dangerous organisms, using techniques like laser technology and mass spectrometry. Unfortunately, the ability to rapidly identify all possible warfare agents in the field remains elusive.

Optical: This type of sensor is very appealing for direct detection of bacteria. This optical sensor detects minute changes in the refractive indexes or thickness, which occur when cells bind to receptors immobilized on the transducer surface ${ }^{[55]}$ (Fig. 9). Optical techniques reported for the detection of bacteria include: monomode dielectric waveguides, surface plasmon resonance, ellipsometry, the resonance mirror and the interferometer. This instrument uses a label-free technique to detect bacteria ${ }^{[55-59]}$. The BDS-240 (Bacteria Detection System) system is an optical unit that consists of an LED/filter excitation source and a photodiode detection system. It is used for positive/negative tests of both aerobic and anaerobic bacteria ${ }^{[56]}$.

Piezoelectric: This system may be used for direct labelfree detection of microorganisms. This technology offers a real-time output, ease of use and cost effectiveness ${ }^{[60-63]}$. The general idea of this technology is based on coating the surface of the Piezoelectric (PZ) sensor with a selective binding substance. For example, placing antibodies in a solution containing bacteria. The bacteria will bind to the antibodies and the mass of the crystal will increase while the resonance frequency of oscillation will decrease ${ }^{[64-66]}$. 
Fluorescence Label: Due to the presence of proteins and polysaccharides in the outer membranes of microorganisms permit the development of immunoassay techniques for bacterial detection. In Fluorescent ImmunoAssays (FIA), fluorochrome molecules are used to label immunoglobulin ${ }^{[64-68]}$. The fluorochrome absorbs short-wavelength light and emits light at a higher wavelength, which is detected using: fluorescent microscopy. Using an antibody to the protective protein co-expressed with anthrax toxins have shown that a device based on this method could be used as an instrument for the presence of anthrax ${ }^{[69]}$.

Electrochemical Immunodetection: This biosensor consists of silicon doped with phosphorous and an insulating layer in contact with an aqueous solution where the immunoreaction takes place ${ }^{[70-74]}$. The difference between the charge distribution on the surface of the insulation layer and the field effect transistor is used to detect changes in the potential at the interface. This sensor has advantages over opticalbased systems because it can offer comparable instrumental sensitivity and is more flexible to miniaturization ${ }^{[55]}$. Traditional immunologic techniques have been used extensively by the military for biological agent detection ${ }^{[75]}$.

Genosensor: Gene probes are associated with ultra sensitive determination of microorganisms, viruses and various chemicals. The sensor includes a nucleic acid, which specifically recognizes and binds to a target. The identification is dependent upon the formation of stable hydrogen bonds between the two nucleic acid strands ${ }^{[76]}$. The bonding between nucleic acids takes place at regular (nucleotide) intervals along the length of the nucleic acid. The specificity of nucleic acid probes relies on the ability of different nucleotides to form bonds only with a proper counterpart ${ }^{[77]}$. This detection of specific DNA sequences provides the basis for detection a wide variety of bacterial pathogens.

Biological Integrated Detection System: The BD is an automatic biological agent detector developed for the U.S. Army Chemical and Biological Defense Command. BIDS ${ }^{[54]}$ consists of a shelter mounted on a dedicated vehicle. The system includes a trailermounted $15-\mathrm{kw}$ generator to provide electrical power. The BIDS Biological Detection Suite links aerodynamic particle sizing, bioluminescence fluorescence, flow cytometry, mass spectrometry and immunoassay (SBCCOM, 2000) ${ }^{[78]}$. The detector includes a number of design features ${ }^{[79]}$.

* Simultaneous detection of up to eight different antigens, including bacteria, viruses and toxins

* Fully automated system

* Specific agent identification

* Fifteen-minute response
* $\quad 95 \%$ detection probability $0.1 \%$ false alarm rate

Pyrolysis-Gas Chromatograph-Mass Spectrometry: Pyrolysis devices coupled to short column gas chromatography/mass spectrometry have the ability to extract microorganisms ${ }^{[23]}$. However, even the most highly prepared combat force will not be able to detect an attack with biological warfare agents until twentyfive to forty minutes after it has been released ${ }^{[80]}$. Because of the high molecular weight that characterizes microorganisms and given the mass limitation of conventional mass spectrometry, a sample-processing module is necessary. This processor module must take the complex, high molecular weight biological agent and break it up into substances small enough to fall within the mass range of a small, portable mass spectrometer ${ }^{[23]}$. A carefully weighed compromise between logistics (module size, consumables and power requirements), operating characteristics (speed of processing, sample size, etc.) and scientific performance (sensitivity, specificity, overall information yield) led to the choice of analytical pyrolysis techniques including "oxidative" Pyrolysis ${ }^{[23]}$. The process is defined as the rapid heating of a sample under an inert atmosphere with the objective of fragmenting the analyst into smaller, individual pieces.

Anthrax DNA Blueprint: The worst outbreak of anthrax occurred in $1979,{ }^{[81]}$ when a biological weapons plant in Russia accidentally released airborne anthrax spores, killing sixty-six people. In 1998 scientists at Los Alamos National Laboratory used newly developed techniques to determine that the spores released in the accident contained at four different strains of anthrax ${ }^{[15]}$. This raised concerns that Russia might have been working on a vaccine-resistant form of anthrax for use as a biological weapon. The United States government previously planned to vaccinate all American personnel against anthrax. However, there is a possibility of genetically engineered new forms of the disease, which will make the vaccination ineffective. Lawrence Livermore is developing two types of fully automated bio detectors for the real-time sample collection, detection and identification in the field ${ }^{[82]}$. Livermore developed a portable PCR that identifies the DNA inside a cell. This technique targets unique sequences on the DNA blueprint of a microorganism. They also developed a miniature flow cytometer that looks at the proteins and other material on the surface of cells. This new detection system can identify several biological agents ${ }^{[82]}$.

\section{CONCLUSION}

Chemical and biological weapons exist and are proliferating. There is considerable precedent for their use. It is clearly in the interest of humankind to prevent the future use of such agents of mass destruction. 
Particularly as they become ever more lethal with advances in Bioengineering. The unpredictable and indiscriminate devastation caused by natural epidemics and hazardous chemicals during wartime without medical treatment should warn humans the dangers of employing them as weapons. Detection techniques should be developed because it will discourage attackers from deploying an agent ".... BW is a weapon of mass destruction. But no agency has done any serious planning about how to defend against a BW attack on our own cities, or those of our allies... We urge DOD to take the initiative, together with the Center for Disease Control and Prevention, in formulating a comprehensive plan for the civil defense against BW attack. If such an attack should occur, the military establishment will be blamed for the failure in national defense, regardless of the purported mandate -and above all, we will blame ourselves" ${ }^{\text {[83] }}$.

There is a regrettable tendency to think about defense against biological and chemical warfare either as unnecessary or as too difficult. Unfortunately, the danger of this warfare did not dissipate with the dismantling of the U.S. offensive program in 1969 and the signing of the Biological Weapons Convention in $1972^{[84]}$. Only by planning and preparing will we be able to diminish the likelihood of these types of weapons. "If we do not stem the proliferation of the world's deadliest weapons, no democracy can feel secure... One of our most urgent priorities must be attacking the proliferation of weapons of mass destruction, whether they are nuclear, chemical, or biological", $^{[40,41]}$.

\section{REFERENCES}

1. Orient, J.M., 1989. Chemical and biological warfare. JAMA, 262: 644-647.

2. Press N., 1985. Haber's choice, Hobson's choice and biological warfare. Perspect. Biol. Med., 29: 92-108.

3. Harris R. and J. Paxman, 1982. A Higher Form of Killing: The Secret Story of Gas and Germ Warfare. London, England: Chatto and Windus Ltd.

4. Anonymous, 1988. The Wall Street J., 1:1, 26.

5. Anonymous, 1984. Chemical and bacteriological weapons in the 1980s. Lancet, pp: 141-143.

6. Bleyer, H. and D. Stremmel, 1985. Stend und Entwicklungstendenzen bei chemischen Kampfstoffen der imperialistischen Lander. Z Gesamte Inn MED., 40: 40-44.

7. Le Chêne, E., 1989. Chemical and biological warfare- Threat to the Future. Toronto, Canada: Mackenzie Institute.

8. Carnes, S.A. and A.P. Watson, 1989. Disposing of the US chemical weapons stockpile: An approaching reality. JAMA, 262: 653-659.
9. Budiansky, S., 1986. Qualified approval for binary chemical weapons. Science, 234: 930-932.

10. Burck, G., 1989. Will Bush be a chemical president? FAS Public Interest Rep., 42: 6-7.

11. Herby, P., 1989. The Paris conference on chemical weapons. Chem. Weapons Convention Bull., pp: 12-13.

12. Dickson, D., 1988. Hopes recede for early ban on chemical arms. Science, 240: 22-23.

13. Cole, L.A., 2000. CBW terrorism Deconstructed. Ed. Jonathan B. Tucker, MIT Press.

14. Cole, L.A., 1999. The Ultimate Terrorist. Ed. Jessica Stern, Harvard University.

15. Cole, L.A., 1998. The poison weapon taboo: Biology, culture and policy. Politics and the Life Sci., 17: 119-132.

16. United Nations, 1970. Basic problems of disarmament. Reports of the Secretary General, New York, United Nations.

17. Cole, L., 1999. Enearta: Chemical and Biological Warfare, The Eleventh Plague: The Politics of Biological and Chemical Warfare. W.H. Freeman and Company.

18. Varfolomeyev, S., I. Kurichkin, A. Eremenko and E. Efremenko, 2002. Chemical and biological safety. Biosensors and nanotechnological methods for the detection and monitoring of chemical agents. Pure and Appl. Chem., 74: 2311-2316.

19. Parker, W.E., W.M. Buckley, S.A. Kreek, A.J. Caffrey, G.J. Mauger, A.D. Lavietes and A.D. Dougan, 2001. A portable system for nuclear, chemical agent and explosives identification. American Institute of Physics Conference Proceedings, 576: 1073-1076.

20. Erickson, B., 1998. The chemical weapons convention redefines' analytical challenges. Anal. Chem., 70: 397A-400A.

21. Anonymous, 2001. Encyclopedia of Analytical Chemistry: Instrumentation and Applications: Chemical Warfare Agents Detection, Meyers R.A., (Ed). Chichester: John Wiley and Sons Ltd.

22. Basche, T., W.E. Moerner, M. Orrit and P. Wilding (Eds.), 1996. Single-molecule Optical Detection, Imaging and Spectroscopy. Published by New York: John Wiley and Sons.

23. Snyder, A.P., W.M. Maswadeh, J.A. Parsons, A. Tripathi, H.L.C. Meuzelaar, J.P. Dworzanski and M.G. Kim, 1999. Field detection of Bacillus spore aerosols with stand-alone pyrolysis-gas chromatography-ion mobility spectrometry. Field Anal. Chem. Tech., 3: 315-326.

24. Jantzen, E. and J. Lassen, 1980. Characterization of Yersinia pestis species by analysis of whole-cell fatty acids. Intl. J. System Bacteriol., 30: 421-428.

25. Kosal, M.E., 2003. The Basis of Chemical and Biological Weapons Detectors. November 24, (CNS). http://cns.miis.edu./research/cbw/index.htm 
26. www.opcw.gov, OPCW Press Releases to the UN, 1997.

27. www.opcw.gov, OPCW Press Releases to the UN, 1998.

28. www.opcw.gov, OPCW Press Releases to the UN, 1999.

29. www.opcw.gov, OPCW Press Releases to the UN, 2000.

30. www.opcw.gov, OPCW Press Releases to the UN, 2001.

31. www.opcw.gov, OPCW Press Releases to the UN, 2002.

32. www.opcw.gov, OPCW Press Releases to the UN, 2003.

33. www.opcw.gov, OPCW Press Releases to the UN, 2004.

34. Mitretek Systems, 1999. Background on Biological Warfare, Mitretek Systems. http:// www. mitretek. org/ mission / envenelchemicall weapons. html.

35. Mitretek Systems, 1999. Chemical Weapons and Dissemination, Mitretek Systems. http: //www. mitretek.org/mission/envenelchemicallweapons.html.

36. Kenneth, T., 2004. Bacillus anthraces and Anthrax. University of Wisconsin-Madison, Department of Bacteriology. http://www.bact.wisc.edu/Bact330/lecture anthrax.

37. Nettleman, M.D., 1991. Biological warfare and infection control. Infection Control and Hospital Epidemiol., 12: 368-371.

38. Newhouse, J., 1989. War and Peace in the Nuclear Age. Published by Alfred A. Knopf, New York, pp: 209-265 and 293-219.

39. WGBH Educational Foundation, 2001. Frontline: Biological Warfare, Public Broadcasting Services (PBS), http://www.Pbs.org/wgbh/pages/frontline/shows/plague.

40. Clinton, B., 1998. Combating Terrorism: Presidential Decision Directive 62. PDD-62, (Presidential Decision Directives). http://www.fas.org/irp/offdocs/pdd/index.html

41. Clinton, B., 1998. Critical Infrastructure Protection. PDD-63, (Presidential Decision Directives).

http://www.fas.org/irp/offdocs/pdd/index.html

42. Eggins, B., 1996. Biosensors: An Introduction. Published by John Wiley and Sons Ltd.

43. Klahre, J. and H.C. Flemming, 2000. Monitoring of biofouling in paper-mill process waters. Water Research, 34: 3657-3665.

44. Strathmann, M., T. Griebe, H.C. Flemming, 2000. Artificial biofilm model- a useful tool for biofilm research. Applied Microbiol. Biotech., 54: 231237.

45. Linos, A., M.M. Berekaa, R. Reichelt, U. Keller, J. Schmitt, H.C. Flemming, R.M. Kroppenstedt and A. Steinbuchel, 2000. Biodegradation of cis-1,4polyisoprene rubbers by distinct actinomycetes: Microbial strategies and detailed surface analysis. Appl. Environ. Microboil., 66: 1639-1645.
46. Flemming, H.C., 2000. Biofilms-life on the edge of the aqueous phase. Nachrichten Aus Der Chemie, 48: 442.

47. Wuertz, S., E. Muller, R. Spaeth, P. Pfleiderer and H.C. Flemming, 2000. Detection of heavy metals in bacterial biofilms and microbial flex with the fluorescent complexing agent Newport Green. J. Industrial Microbiol. Biotechnol., 24: 116-123.

48. Paddle, B., 1996. Biosensors for chemical and biological agents of defense interest. Biosensors \& and Bioelectronics, 11: 1079-1113.

49. Kaminski, P., 1994. Report of the Defense Science Board Task Force on Persian Gulf War Health Effects Memorandum for Under Secretary of defense, Defense Science Board, June, http://www.gulflink.osd.rnilldsbrpt.

50. Published separately and available on GulfLINK are information papers on the M8A1 Chemical Alarm System and the Fox NBC Reconnaissance Vehicle. Special Assistant for Gulf War Illnesses, Web site www.gulflink.osd.mil.

51. Browning, D.R., 1979. Development of the M256 Chemical Agent Detector Kit. US Army Chemical Systems Laboratory (CSL) Technical Report \#ARCSL-CR-78020, Aberdeen Proving Ground, MD, pp: 9, 10.

52. US Army Office of the Surgeon General, 1997. Excerpted from Textbook of Military Medicine: Warfare, Weaponry and the Casualty; Medical Aspects of Chemical and Biological Warfare, pp: 220.

53. Wilkins, E., 1998. Towards implantable glucose sensor. J. Biomed. Engg., 11: 353-440.

54. M31E1 Biological Integrated Detection System (BIDS), 2000. http://www.fas.org/man/dod101/sys/land/bids.htm.

55. Ivnitski, D., B. Solomon, G. Fleminger and J. Rishpon, 1998. An amperometric biosensor for real time analysis of molecular recognition. Bioelectrochem. Bioenerg., 45: 27-32.

56. Ivnitski, D., I. Abdel-Hamid, P. Atanasov and E. Wilkins, 1999. Biosensors for detection of pathogenic bacteria. Biosensors and Bioelectronics, 14: 599-624.

57. Griffiths, D. and G. Hall, 1993. Biosensors: What real progress is being made? Trends in Biotechnol., 11: 122-130.

58. Owen, V.M., 1994. Market requirements for advanced biosensors in health-care. Biosensors \& and Bioelectronics. 9: R29-R35.

59. Harris, C.M. and D.B. Lell, 1985. The estimation of microbial biomass. Biosensors, 1: 17-84.

60. Salzman, G., S.B. Singham, R.G. Johnson and C.F. Bohren, 1990. Light Scattering and Cytometry. In: Melamed, M.R., Lindmo, T., Mendelsohn, M.L., (Eds.) Flow Cytometry and Sorting. John Willey, New York, pp: 105-153. 
61. Morgan, C.L., D.J. Newman and C.P. Price, 1996. Immunosensors: Technology and opportunities in laboratory medicine. Clin. Chem., 42: 193-209.

62. He, F.J., G.Q. Geng, W.H. Zhu, L.H. Nie, S.Z. Yao and C. Meifeng, 1994. Rapid detection of Escherichia coli using a separated electrode piezoelectric crystal sensor. Analytica Chimica Acta, 289: 313-319.

63. Schmitt, N., L. Tessier, H. Watier and F. Patat, 1997. A new method based on acoustic impedance measurements for quartz immunosensors. Sensors and Actuators B-Chemical., 43: 217-223.

64. Bunde, R.L., E.J. Jarvi and J.J. Rosentreter, 1998. Piezoelectric quartz crystal biosensors. Talanta, 46: 1223-1236.

65. Nelson, W.H. (Ed.), 1985. Instrumental Methods for Rapid Microbiological Analysis. $\mathrm{VCH}$ Publishers, USA, pp: 219.

66. Bird, J.A., M.C. Easter, S.G. Hadfield, E. May and M.F. Stringer, 1989. Rapid Salmonella detection by a combination conductance and immunological techniques. In: Soc. Appl. Biotechnology Tech. Series, 25: 165-183.

67. Lloyd, D. (Ed)., 1993. Flow Cytometry in Microbiology. Published by Springer-Verlag London Limited, Germany, pp: 188.

68. Perez, F.G., M. Mascini, I.E. Tothill and A.P.F. Turner, 1998. Immunomagnetic separation with mediated flow injection analysis amperometric detection of viable Escherichia coli O157. Anal. Chem., 70: 2380-2386.

69. Wijesuriya, D.C., G.P. Anderson and F.S. Ligler, 1994. A rapid and sensitive immunoassay for bacterial cells. In: Berg, D.A., Williams, J.D., Reeves, J., Reevs P.J. (Eds.), Proceedings of the 1993 ERDEC Scientific Conference on Chemical Defense Research, Report No. ERDEC-SP-024, pp: 671-677.

70. Libby, J.M. and H.G. Wada, 1989. Detection of Neisseria-meningitidis and Yersinia-pestis with a novel silicon-based sensor. J. Clin. Microbiol., 27: 1456-1459.

71. Lee, W.E., T.V. Jacobson and H.G. Thompson, 1993. Characteristics of the biochemical detector sensor. Defense Research Establishment Suffield, Canada. Suffield Memorandum No. 1402, pp: 123.

72. Lee, W.E., H.G. Thompson, J.G. Hall, R.E. Fulton and J.P. Wong, J.P., 1993b. Rapid immunofiltration assay of Newcastle disease virus using a silicon sensor. J. Immunology. Methods, 166: 123-131.

73. Gehring, A.G., D.L. Patterson and S.I. Tu, 1998. Use of a light-addressable potentiometric sensor for the detection of Escherichia coli 0157: H7. Anal. Biochem., 258: 293-298.
74. Gehring, A.G., C.G. Crawford, R.S. Mazenko, L.J. VanHouten and J.D. Brewster, 1996. Enzymelinked immunomagnetic electrochemical detection of Salmonella typhimurium. J. Immunology. Methods, 195:15-25.

75. Bruno, J. and J. Kiel, 1999. In vitro selection of DNA aptamers to anthrax spores with electrochemilumineseence detection. Biosensors \& and Bioelectronics, 14: 457- 464.

76. Wang, J., G. Rivas, X. Cai, E. Palecek, P. Nielsen, H. Shiraishi, N. Dontha, D. Luo, C. Parrado and M. Chicharro, 1997. DNA electrochemical biosensors for environmental monitoring. A review. Analytica Chimica Acta, 347: 1-8.

77. Wang, J., G. Rivas, C. Parrado, X.H. Cai and M.N. Flair, 1997. Electrochemical biosensor for detecting DNA sequences from the pathogenic protozoan Cryptosporidium parvum. Talanta, 44: 2003-2010.

78. SBCCOM Online, 2000. Biological Integrated Detection System (BIDS), Edgewood Chemical Biological Center, http://www.sbccom.apgea.anny.mil/products/bids.h tm.

79. Biological Detector (BD) -The BD was jointly developed and field-tested by ETG and the U.S. Army. http://nbcindustrygroup.com/env.htm .

80. Scholl, P., M. Leonardo, A. Rule, M. Carlson, M. Antoine and T. Buckley, 1999. The development of matrix-assisted laser desorptionllonization time-offlight spectrometer for the detection of biological warfare agent aerosols, John Hopkins APL Technical Digest, 20: 343-351.

81. http://www.lanl.gov/orgs/pa/News/BL-3info.html. 1998.Information Sheet: Proposed Biological Research Activity.

82. Milanovich, F., 1998. Reducing the threat of biological weapons. Sandia National Laboratories. California Site. Livermore.

83. McCuen, G., 1999. Biological terrorism and weapons of mass destruction. 6. E. McCuen Publications.

84. Danzig, R., 1996. Biological warfare: A nation at risk, A time to act. Institute For National Strategic Studies, Number 58, http://www.ndu.edulinss/strforuni/forum58.html 